\title{
The ultrastructure and building of graptolite dissepiments
}

Adam Urbanek and Piotr Mierzejewski

Acta Palaeontologica Polonica 54 (2), 2009: 243-252 doi:http://dx.doi.org/10.4202/app.2006.0020

Dissepiments or connecting bars between adjacent stipes in rhabdosomes of dendroid graptolites were studied by means of electron microscopy (SEM and TEM). Thematerial, chemically isolated from rockmatrix, originating from the Ordovician of Estonia and glacial boulders of Baltic origin found in Poland, is assigned provisionally to the genus "Dictyonema" sensu lato. Early growth stages of dissepiments are made only of the fusellar component. Older dissepiments are composed of the central core and the outer envelope: the central core is made of rather irregularly arranged growth units made of the fusellar tissue, whereas the outer envelope has a distinct cortical appearance. TEM observations indicate that the fusellar component is made of both typical fusellar and microfusellar tissues (the latter with complete and reduced microfuselli). The cortical component of dissepiments is made both of dependent and independent cortex. The opinion is advanced that the dissepiments were constructed externally by themortaring activities of zooids, similar to that of Recent Cephalodiscus. Our observations indicate that bizooids were most probable dissepiment constructors. These results, in general, does not support earlier opinions that dissepiments are made of cortical tissue acquiring a fusellar aspect in some cases, and that dissepiments were produced by the extrathecal membrane surrounding the rhabdosome.

Key words: Hemichordata, Graptolithoidea, Dendroidea, Dictyonema, dissepiments, skeletal tissues, ultrastructure, Ordovician.

Adam Urbanek [urbanek@ twarda.pan.pl], Instytut Paleobiologii PAN, ul. Twarda 51/55, PL-00-818 Warszawa, Poland; Piotr Mierzejewski [mierzejewski@ post.pl], Instytut Paleobiologii PAN, ul. Twarda 51/55, PL-00-818 Warszawa, Poland. Present address: ul. Filtrowa 83/49, PL-02-032 Warszawa, Poland.

This is an open-access article distributed under the terms of the Creative Commons Attribution License (for details please see creativecommons.org), which permits unrestricted use, distribution, and reproduction in any medium, provided the original author and source are credited. 
Fof Full text $(1,087.5 \mathrm{kB})$ 